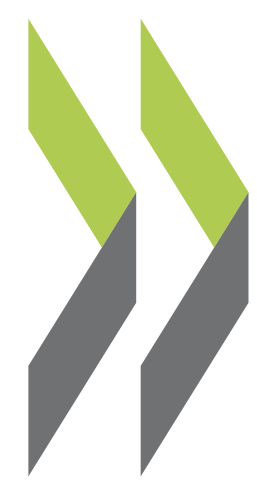

OECD Working Papers on Insurance and Private Pensions No. 4

\title{
Governments and the Market for Longevity-Indexed Bonds
} Pablo Antolín, Hans J. Blommestein 


\section{OEC}

GOVERNMENTS AND THE MARKET FOR LONGEVITY-INDEXED BONDS

Pablo Antolin and Hans Blommestein

January 2007

OECD WORKING PAPER ON INSURANCE AND PRIVATE PENSIONS

No. 4

Financial Affairs Division, Directorate for Financial and Enterprise Affairs

Organisation for Economic Co-operation and Development

2 Rue André Pascal, Paris 75116, France

www.oecd.org/daf/fin 


\section{ABSTRACT/RÉSUMÉ}

\section{Governments and the market for longevity-indexed bonds}

Uncertainty about length of life, longevity risk, is a growing financial problem for pension funds and annuity providers. They would like to transfer longevity risk away to institutions better placed to deal with it. Unfortunately, there is a lack of financial instruments to hedge against this longevity risk, thereby complicating risk management by pension funds and hindering the expansion of the annuity market. Consequently, this paper examines the role of government in promoting a private market solution for longevity hedging financial products. Governments could improve the market for annuities by issuing longevity indexed bonds and by producing a longevity index. The paper argues though that this public policy role is hampered by the fact that governments are themselves are already exposed to significant longevity risk. However, governments could take other steps such as producing a longevity index.

JEL codes: G23, G28, D8, J11, J26, J32, C15, C32

Keywords: Uncertainty; longevity risk; pension funds; DB and DC plans; annuities; financial instruments; hedging; longevity-indexed bonds; indices; longevity index.

$$
* * * * *
$$

\section{Le gouvernement et le marché pour les titres indexés sur la longévité}

L'incertitude sur la durée de vie, le risque de longévité, est un problème financier croissant pour les fonds de pension et les fournisseurs de rentes viagères. Ils préfèrent transférer ce risque aux institutions les plus préparées pour les absorber. Malheureusement, il y a un manque d'instruments financiers afin d'avoir une couverture contre le risque de longévité. Cette situation complique le management du risque et empêche l'expansion du marché de la rente viagère. Par conséquent, ce document étudie le rôle du gouvernement pour promouvoir une solution dans le marchée privée des produits financiers qui couvrent le risque de longévité.

Les gouvernements pourraient améliorer le marché des rentes viagères en émettant des titres indexés sur la longévité et en produisant un indice sur la longévité. Ce document soutient cependant que ce rôle de politique publique est amoindri par le fait que les gouvernements eux-mêmes sont déjà exposés de manière significative au risque de longévité. Néanmoins, les gouvernements pourraient prendre d'autres chemins tels que la production d'un indice de longévité.

Classification JEL: G23, G28, D8, J11, J26, J32, C15, C32

Mots clés: Incertitude; risque de longévité; fonds de pensions; plans de pension de prestation définie et contributive; viager; instruments financiers; titres indexe a la longévité; index; index de longévité.

\section{Copyright OECD, 2007}

Applications for permission to reproduce or translate all, or part of, this material should be made to: Head of Publications Service, OECD, 2 rue André-Pascal, 75775 Paris Cédex 16, France. 


\title{
GOVERNMENTS AND THE MARKET FOR LONGEVITY-INDEXED BONDS
}

\author{
P. Antolin and H. Blommestein ${ }^{1}$
}

\section{Introduction}

1. Uncertainty about future improvement in mortality and life expectancy poses important risks. Increased longevity is a long-term trend, seemingly in one direction only. At the heart of longevity as a problem for society is uncertainty about the rate of improvements in life expectancy and mortality that may have an adverse impact on social welfare. This uncertainty is mainly about speed and magnitude, not the direction. Uncertainty about length of life, that is longevity risk, carries the risk that individuals run out of resources, thereby forcing them to reduce their standard of living at old age. Longevity risk is also a growing financial problem for private companies and governments that manage defined-benefit pension schemes as well as for annuity providers. They run the risk that the net present value of their pension promises and annuity payments will turn out higher than expected, as they will have to pay out a periodic sum of income that will last for an uncertain life span. Longevity risk is therefore a problem for defined benefit programmes and annuity products.

2. Unfortunately, there is a lack of financial instruments to hedge against this longevity risk. Pension funds and annuity providers would like to transfer longevity risk away to institutions better placed to deal with it. However, although financial instruments to hedge against interest rate and inflation risks are readily available, there is a lack of similar instruments to hedge against longevity risk, thereby complicating risk management by pension funds and hindering the expansion of the annuity market. Consequently, governments could encourage ways in which annuity providers and DB-plan sponsors could better hedge their life expectancy risks, for example, supporting market-based solutions to addressing longevity risk.

3. This paper examines therefore the role of government in promoting a private market solution for longevity hedging financial products. In this regard, the paper first examines in Section 2 different channels to transfer longevity risk emphasizing the prospects for capital market solutions. It concludes that in practice it is unlikely that the private sector will be successful in the short-term. In this context, Section 3 examines the failure of the so far only longevity hedging bond issued by a private institution. Section 4 argues that the problem with market solutions is that longevity risk does not manifest itself only as idiosyncratic risk (unique to each individual) but also as an aggregate risk (uncertainty about overall rates of population mortality improvement). As a result of this aggregate longevity risk, private sector driven market in longevity products is unlikely to develop in the near future. Moreover, annuity providers are

\footnotetext{
${ }^{1}$ The authors would like to thank Andé Laboul, Fionna Stewart and Juan Yermo for comments on earlier drafts. They also thank delegates to the Working Party on Private Pensions of the OECD Insurance and Private Pensions Committee for useful discussions, and participants at the SUERF meeting in Lisbon on October 12, 2006. The views expressed herein are those of the authors and do not necessarily reflect those of the OECD or the governments of its Member countries. The authors are sole responsible for any errors.

Contact information: Pablo Antolín or Hans Blommestein, Financial Affairs Division, Directorate for Financial and Enterprise Affairs, Organization for Economic Co-operation and Development, 2, rue André Pascal, Paris 75116, France. E-mail: pablo.antolin@oecd.org; hans.blommestein@oecd.org
} 
forced to charge higher prices per unit of annuity pay-out so as to compensate for this un-hedged aggregate risk.

4. In this context, governments could improve the market for annuities by issuing longevity indexed bonds and by producing a longevity index. Governments could provide pricing benchmarks and liquidity by issuing survivor or longevity indexed bonds (Blake and Burrows, 2001). However, this may in practice be a problem as they are themselves heavily exposed to longevity risk through public pension systems and social security schemes (Blommestein, 2006). Section 5 therefore examines the amount of longevity risk already incorporated in governments' balance sheets to conclude that governments are already exposed to significant longevity risk. But governments can encourage or support the development of a private market in longevity hedging products, for example, by producing a reliable and widely accepted longevity index to be used as a benchmark for pricing hedging products. In this regard, Section 6 discusses a tentative proposal for a longevity index bond that governmental institutions, in particular national statistical institutes could develop. The final section of the paper summarises the main conclusions.

\section{Channels to transfer longevity risk.}

5. Pension funds and annuity provides could manage the risk that their pay-out commitments may turn out to be higher than expected (longevity risk) by transferring this risk. This section looks therefore into several channels available to transfer this risk concluding that it is unlikely the private sector will be successful in the short term.

6. Pension funds and annuity providers can transfer longevity risk through the financial system or directly to individuals. Transferring longevity risk to individuals has been done by shifting from defined benefit to defined contribution pension plans, as well as by offering fixed-term annuities where the length of time the annuitant will be receiving payments is capped. ${ }^{2}$ Transferring the longevity risk of pension funds and annuity providers through the financial system can in principle take place via four principal channels: ${ }^{3}$

- Protection seeker takes insurance from re-insurers.

- Conversion of DB benefits to annuities via bulk "buy outs".

- Annuity provider writes balancing insurance product.

- Capital market solutions.

7. Re-insurance companies have a fairly limited underwriting capacity. As a rule, re-insurers do not take on longevity risk, unless it is for an existing client and part of an overall package of risks, while capped at a relatively small level (Richards and Jones, 2004). As a result, the appetite of re-insurers for

\footnotetext{
${ }^{2}$ The self-insurance by individuals of longevity risk is however generally inefficient. It is welfare improving to have retirement income annuitize at retirement as consumption will be maximised and the risk of outliving one's resources is removed (Yaari, 1965).

${ }^{3}$ Thomas Schroeder and David Clark, What are the key factors that will drive the longevity bond market?, paper presented at the "Seventh Annual OECD-World Bank Global Bond Market Forum", held on 23-24 May 2005 in Washington D.C; Stephen Richards and Gavin Jones (2004), Financial aspects of longevity risk, Paper presented to the Staple Inn Actuarial Society, London, 26 October 2005; Morgan Stanley, Challenges to Market Development, Presentation at the First International Conference on Longevity Risk and Capital Market Solutions, 18 February 2005, London.
} 
longevity risk transaction seems to be rather small at this stage, although this situation can improve with more precise knowledge of this risk and growing risk transfer demand.

8. Also the capacity of the buy-out market is rather small. The conversion of DB benefits to annuities is both very expensive, while insurance capacity is very limited. Actually, the UK buy-out market has shrunk, with only two major re-insurers active (Bryne and Harrison, 2005).

9. The third way of transferring longevity risk is based on hedging through balancing products. An obvious example is the case where a holder of longevity risk would enter into a contract with a term assurance portfolio, thereby combining a conventional level annuity with a whole-life assurance to the value of the cost of the annuity. The resulting combination of the underlying risks (mortality and longevity risk) would then reduce an insurer's exposure to future increases in longevity, thereby also reducing the capital reserves held in respect of this risk.

10. The very limited capacity of the first three channels for transferring longevity risk has prompted the search for capital market solutions. The capital market channel for transferring longevity risk would allow protection seekers to buy longevity bonds. Proposed solutions for reducing the exposure to longevity risk of pension funds and annuity providers are conceptually simple, as they require the construction of capital market instruments linked to a reliable longevity index. Given a suitable index it would be possible to construct longevity bonds with either the coupon or principal (or both) at risk of default if longevity improvements in excess of expectations occurred (Richards and Jones, 2004). These instruments can then be used to hedge mortality and longevity risk. ${ }^{4}$ Although life insurers and pension funds have similar liabilities, they have different perspectives (Roberts, 2005). Insurance companies are concerned about potential catastrophic losses, while pension plans aim to protect corporate cash flows from incremental losses.

11. However, in practice it is unlikely that the private-sector will be successful in the short-term, ${ }^{5}$ as the experience of the only longevity indexed bond issue by a private institution, examined in the next section, seems to suggests.

\section{Why the EIB/BNP longevity bond failed? ${ }^{6}$}

12. The only longevity indexed bond issued by a private institution failed to generate enough demand. This longevity indexed bond was structured by BNP Paribas and issued by the European Investment Bank (EIB). ${ }^{7}$ The EIB/BNP longevity bond was only issued for the UK pension market as its payments were linked to a cohort survivor index based on the realised mortality rates of males aged 65 in 2003 in England and Wales.

\footnotetext{
${ }^{4}$ This is likely to be a partial hedge as in practice significant basis risk - a portfolio of annuitants or members of pension plans or insurance schemes may exhibit a very different pattern of longevity improvements compared to the underlying index for a bond - will remain in portfolios or pension and insurance schemes. For example, Fernandes (2005) argues that basis risk could be of the order of $20 \%$.

${ }^{5}$ Research has identified a number of key obstacles that explain why a large scale private-sector driven market in longevity products is unlikely to develop in the near future (Blommestein, 2006).

${ }^{6}$ This section has benefited from discussions at the OECD's Committee for Financial Markets, and, in particular, from Eric Perée.

${ }^{7}$ The bond was priced by taking the projected survival rates produced by the UK Government Actuary's Department (GAD) and these were discounted at LIBOR minus 35 basis points to give the issue price. The risk associated with differences between experienced mortality and the GAD projections were passed to a reinsurance company, Partner Re, leaving the EIB with an after longevity swap with plain vanilla interest rate finance.
} 
13. There are several factors that explain this failure. The immediate explanation for its failure was to argue that it was overpriced. However, most studies consider that the EIB/BNP longevity bond was not overpriced, if any, it was under-priced (Cairns et al., 2005; and Friedberg and Webb, 2005). Obviously, the lack of demand suggests that at the asked price other concerns, not taken on board by the models used to assess the adequacy of its pricing, weighted against more heavily.

14. Among those factors, the EIB/BNP longevity bond failed because longevity risk is an economic risk different from interest rate or inflation risks. Furthermore, longevity risk is a long-term risk with low volatility. Moreover, asset-liability matching rules and other regulatory requirements are not effective in encouraging pension funds to hedge this aggregate risk. There were therefore no regulatory benefits for UK pension funds for subscribing this longevity bond. In addition, pension funds use current mortality tables without forecasts, and only adjust mortality assumptions every 10 years with new tables (Antolin, 2006). Therefore there are insufficient incentives to internalise the cost of unexpected gains in longevity.

15. There were also problems with the design of the issue. First, the bond issued had a limited longevity index. The coupon was linked to the survivor index of men in England and Wales. Secondly, it had a limited coverage because the maximum longevity was capped at 25 years. Therefore, it was a partial hedge as the risk arising from an increase in longevity beyond the cap would not be hedged by the bond. And thirdly, because of regulatory reforms implemented in the United Kingdom at the time, pension managers were more focus on other regulatory issues (e.g. ALM).

16. Finally, it is argued that trustees and pension fund managers did not seem to understand the utility of the product. Pension fund trustees found it difficult to comprehend. While the basic idea was relatively straightforward and easy to understand, pension fund trustees had to assess how such an instrument would fit in the overall pension portfolio and examine all the potential consequences (economic, financial, regulatory, etc). This is a lengthy process and there is a clear sunk cost in bringing such an ice-breaker transaction to the market. ${ }^{8}$

17. Despite of these issues, a privately issued longevity indexed bond addressing these problems may succeed. Yet, as a result of these issues and other key obstacles examined in the next section, many analysts have proposed a central capital market role for public policy. However, as next section discusses, this public policy role is hampered by several factors.

\section{Governments and efficient sharing of longevity risk.}

18. The role of public policy on sharing longevity risk depends on the distinction between individual and aggregate longevity risk. Idiosyncratic, individual or micro longevity risk (survival risk) can in principle be tackled in an efficient risk sharing fashion via annuities markets. Unfortunately, private annuity markets are affected by adverse selection. Government action (in the form of e.g. mandatory participation rules) can in principle address this type of market failure. Aggregate, macro or cohort longevity risk affects current cohorts in roughly the same way. Positive correlations across individuals mean that private market solutions cannot be used to share this risk efficiently (Bohn, 2005). Common tools to minimise exposure to this macro risk (diversification across cohorts, international diversification via cross-border investments, risk sharing with annuitants, or hedging of insurance companies by selling both annuities and life-insurance) cannot completely eliminate it.

\footnotetext{
${ }^{8}$ The issuance of the longevity indexed bond required the arrangement of a derivative transaction as the EIB is not a natural seller of longevity protection. Therefore, longevity risk would have been passed to a re-insurer. If it is possible to structure a derivative in that way, it is clear that the longevity risk could be transferred through a swap without having a longevity bond. Naturally this would be different if the bond issuer was a natural holder of long longevity positions.
} 
19. Financial markets (including insurance) work efficiently for sharing short-term risks between cohorts (with largely overlapping lifetimes) but not for the long-term life risks of older cohorts that are largely known when the younger cohorts arrive. Ex ante efficient intergenerational risk sharing via private markets is therefore not possible as future generations cannot be included.

20. The government, on the other hand, can use fiscal policy (taxes, social insurance, transfers and public debt) as a vehicle to spread risk across generations, thereby (in theory) improving social welfare. To put it differently, governments have in principle the ability to make markets more complete by providing longevity insurance backed by future generations (Brown and Orszag, 2006).

21. However, government interventions need to take several considerations into account (Bohn, 2005). First, government policy needs to include important general equilibrium effects of aggregate longevity risks. A (permanent) macro longevity shock not only increases systematically life spans, but has also macro-economic effects via changes in factor prices and the capital-labour ratio. It is therefore possible that a longevity shock will increase the (future) supply of labour and decrease (future) wages. ${ }^{9}$

22. A second consideration is that future ("new") generations are subject to at least the same longevity shock as the current ("old") generation. But the key difference in terms of impact is that the new generation can use their entire life-span to adjust labour supply, consumption and savings to a jump in longevity, while this is not the case for the old generation (Brown and Orszag, 2006). This perspective creates the possibility of creating welfare gains by sharing some of the financial risks of longevity shocks for the old generation with future generations. And only the government has the power to enforce intergenerational contracts. ${ }^{10}$

23. A third consideration is that although governments have in principle the tools to spread efficiently longevity risk across generations, this may not occur in practice. Optimal inter-generational risk-sharing may be distorted by taxes (Bohn, 2005) and social security arrangements (Brown and Orszag, 2006). This means that the optimal degree of inter-generational risk-sharing has not been moved onto the right generation. Governments are already heavily involved in inter-generational risk-sharing via public pensions and other social security arrangements. It is difficult to demonstrate but the distorting influence of "politics" makes it unlikely that this is the optimal amount of risk-sharing. For the same reason it is likely that to-days' inter-generational arrangements favour the current generation (of voters) at the expense of future generations (Heller, 2003).

24. Finally, governments themselves are - on a balance sheet basis -- already exposed to longevity risk. Depending on the amount of this exposure, the proposed central capital market role for public policy by issuing longevity-indexed bonds will be hampered as it will further increase the government exposure to longevity risk.

\section{What is the exposure of governments to longevity risk?}

25. The aim of this section is therefore to assess the amount of longevity risk already incorporated in the balance sheet of national governments resulting from their public pension systems. For this purpose, the paper uses data from the latest report by the Economic Policy Committee and the European Commission (DG ECFIN) examining the impact of ageing on public expenditure over the period from

\footnotetext{
${ }^{9}$ Brown and Orszag (2006) note that via these general equilibrium effects, future generations would already share (partially) in longevity risk.

${ }^{10}$ Although (future) politicians can always break these contracts. Pension reform is to a large degree synonymous with breaking inter-generational contracts. Hopefully, reform results in moving away from a non-optimal degree of inter-general risk-sharing.
} 
2005 to 2050 (EC, 2006). The EC exercise provides a measure of the impact of ageing on public finances due to increases in life expectancy that affect the dependency ratio, as well as a sensitivity analysis of the impact of ageing to changes in the underlying assumptions regarding life expectancy.

26. The impact of longevity on public finances stems from both foreseeable and unforeseeable improvements in life expectancy. However, as longevity risk refers to the uncertainty surrounding future life expectancy outcomes, only the impact of unforeseeable changes in life expectancy measures longevity risk. However, in the case of social security, as benefits are in general independent of changes in life expectancy, any improvement in life expectancy even if foreseeable will increase public expenditure.

\section{The impact of foreseeable improvements in life expectancy}

27. The impact of foreseeable improvements in life expectancy can be gauged by examining the impact of the dependency ratio of the very old (those aged 80+) on public finances. The impact of ageing on public finances can be broken down into its constituent parts: the pure impact of demographics, the impact of labour markets and the impact of the parameters of the pension systems. ${ }^{11}$ The effect of increases in the dependency ratio measures the pure demographic impact. Additionally, increases in the dependency ratio are due to the gradual shift of the baby boom generation from the workforce into retirement, the increase in life expectancy implicitly assumed in the projections, and the smaller size of the cohorts entering the labour market. Therefore, the impact on public expenditure of improvements in life expectancy can be gauged by separating this effect from the other two factors. This can be achieved by assuming that the increase in the share of people aged $80+$ is a measure of the population impact of improvements in life expectancy. ${ }^{12}$

28. As the increase in the dependency ratio is just over 50 percent due to increases in the share of those aged 80+, improvements in life expectancy will increase pension expenditure around 4.5 percent of GDP. Using the projected changes in the size and age structure of the population reported in Table 1, the change in the dependency ratio (people aged 65+ over people aged 15 to 64) from 2004 to 2050 can be disaggregated into the change in the ratio of people aged 65 to 79 over the working age population and the change in the ratio of people aged $80+$ over the working age population. The changes in these three ratios for the EU15 are 26.04, 12.5 and 13.6 percent, respectively. Taking the share of those aged 80+ constant at its 2004 level, the increase in the dependency ratio would only be 12.5 percentage points instead of 26 . Therefore, just over 50 per cent of the increase in the dependency ratio is due to an increase in the proportion of people aged $80+$, that is, to improvements in life expectancy. Therefore, as the projected increase in public pension expenditure due to increases in the dependency ratio is 8.2 percent of GDP for the EU15 and 8.6 for the EU25 (Table 2), ${ }^{13}$ the increase due to projected improvements in life expectancy could be around 4.5 percentage points of GDP.

[Table 1 Projected changes in the size and age structure of the population, 2004-2050.]

\footnotetext{
${ }^{11}$ See Table 3.12 and associated explanations in the EC (2006) report.

${ }^{12}$ The choice of age $80+$ as a threshold it based on practical considerations. The average life expectancy at birth or at age 65 is just below age 80. It would have been better to use the exact average life expectancy as a threshold, but unfortunately the breakdown available is between people aged 65-79 and people aged 80+, which, nevertheless, it is quite close to the threshold determined by the average life expectancy.

${ }^{13}$ According to table 2, the total projected increase in pension expenditure is 2.3 percentage points for the EU15. This increase is the result of 8.2 percentage points increase due to the pure demographics effect or ageing and to 1.0, 1.7, and 2.8 percentage points decrease due to projected improvements in employment ratios, reductions in the share of pensioners and the average pension relative to GDP per worker, respectively.
} 
[Table 2 Change in public pension expenditure from 2004 to 2050, contributions to this change and sensitivity analysis]

29. However, this increase in pension expenditure is due to foreseeable improvements in life expectancy, which is, strictly speaking, not a proper measure of longevity risk. Nevertheless, as long as this (expected) impact is not addressed, public pension systems would be under longevity-induced financial pressures.

\section{The impact of unforeseeable improvements in life expectancy}

30. The impact of unforeseeable improvements in life expectancy, on the other hand, is gauged by the sensitivity analysis to changes in life expectancy. Longevity risk is the risk that future life expectancy outcomes turn out differently than expected. Therefore, only the impact of unforeseeable changes in life expectancy can be thought of as longevity risk. Fortunately, the sensitivity analysis regarding the impact of changes in life expectancy on public expenditures provides a good proxy for the amount of longevity risk bore by the public sector over the next 45 years.

31. This sensitivity analysis suggests that an unforeseeable improvement of around 1-1.5 years in life expectancy amounts to an increase in public pension expenditure of 0.3 percentage points of GDP. The EC report (EC, 2006) calculates the change in pension expenditure that would result of an improvement of life expectancy of around 1-1.5 years by 2050 over the increase already implicit in the underlying assumptions. ${ }^{14}$ This improvement would increase public pension expenditure by 0.3 percentage points of GDP over the period 2004-2050 (Table 2).

32. However, the amount of longevity risk already incorporated in the balance sheet of governments may be closer to 1.2 percentage points of GDP. The increase in life expectancy at birth assumed in the EU (2006) report is around 1.1 year per decade, while the increase over the past 50 years has been closed to 2.2 years per decade (DAF/AS/PEN/WD(2006)8). ${ }^{15}$ Therefore, if increases in life expectancy continue according to past trends, life expectancy at birth could be 4-4.5 years higher than the increase implicitly assumed in the baseline EU projections. Assuming a proportional impact of each additional year increase in life expectancy, results in longevity risk being equal to 1.2 percentage point of GDP due to the public pension system.

33. As a result, governments face challenging budgetary pressures. This amount of longevity risk is much less than the 8.2 percent of GDP projected impact of ageing populations on public finances, or the 4.5 percent of GDP impact of improvements in life expectancy already incorporated in the projections. However, if this longevity risk of 1.2 percent of GDP would materialise, the corresponding higher spending would have to be meet by a reallocation of resources from other spending items (e.g. social assistance, education), an increase in tax revenues of 1.2 percent of GDP or an increase in the budget deficit of 1.2 percent of GDP.

34. Therefore, the proposed central capital market role for public policy by issuing longevity-indexed bonds is hampered by the fact that - on a balance sheet basis -- governments themselves are already

\footnotetext{
${ }^{14}$ The underlying assumptions for calculating the impact of ageing on public expenditures reported in the EC report and Table 2 (first three columns) include an average increase in life expectancy of 1.1 years per decade.

${ }^{15}$ The EC projections fail to assess the uncertainty surrounding future increases in life expectancy. Life expectancy may increase 1.1 years per decade as implicitly assumed in the EC projections, 2.2 years per decade or another number. Unfortunately, since the EC exercise follows a deterministic approach instead of a stochastic approach, it is not possible to attach likelihoods to increases in life expectancy and pension expenditures.
} 
exposed to significant longevity risk. The above calculations showed that impact of improvements in life expectancy on public pension expenditures in EU countries over the next 45 years could be around 4.5 percentage points of GDP. Additionally, the amount of longevity risk that the public sector bears in its balance sheet may be around 1.2 percentage points of GDP. This means that by issuing longevity-indexed bonds governments would further increase their current exposure to improvements in life expectancy.

35. On the other hand, some OECD governments have recently implemented measures aiming at reducing their exposure to longevity risk, for example, by linking pension benefits to changes in life expectancy. As a result of these measures, longevity risk is being shifted to individuals increasing inefficiency. ${ }^{16}$ Governments, by issuing longevity indexed bonds governments, could encourage a private market in longevity hedging products, helping pension funds and insurance companies in providing DB plans and annuities which, in turn, protect individuals against longevity risk. The resulting increase in private pension retirement provision would increase market efficiency ${ }^{17}$ and would allow governments to continue reducing their exposure to longevity risk.

36. Additionally, governments still can play an important role in overcoming a number of important difficulties related to market practicalities such as indices and types of indexation. Indices need to be developed so they can be embedded in longevity-indexed bonds. Since these indices provide the benchmark against which future mortality will be measured, they need to be simple and transparent, based on robust data, statistically credible, and calculated in an unbiased manner (Roberts, 2005). Statistics produced by government agencies can meet these criteria as long as they can act as independent professional institutions (i.e. they need to be free from day-to-day political pressures).

\section{Developing a longevity index?}

37. This section presents therefore a tentative proposal to develop an index for longevity risk. Governmental institutions, in particular national statistical institutes, could encourage or promote a market for longevity indexed products by developing an index for longevity risk to be used as a benchmark in markets for longevity bonds and annuities. In order to design such an index, this section first defines a longevity index and then examines what this index should ideally measure.

38. An index is an indicator expressing a relationship: on an ordinal scale, or a number on a cardinal scale, expressing a price, value, or level of an entity in comparison to something else or to a previously established base number. An index number can therefore indicate relative changes. The base level is usually arbitrarily set at 100 , and the increase or decrease in index numbers over time is often expressed as a percentage change.

39. A longevity risk index could indicate the probability that life expectancy for individuals at age $\mathrm{i}$ in year $t$ will be $m$ years higher than the central forecast for life expectancy, LRI (i,t,m). National statistical institutes could provide this index for all ages and for all years from the latest available information up to $\mathrm{n}$ years. They could also calculate the index for different population subgroups according socio-economic characteristics (e.g. gender, income and educational level). Having indices for different population subgroups would help pension funds and insurance companies calculate weighted average indices according to their specific membership structure (Antolin, 2006).

40. In order to calculate a longevity risk index, governmental institutions would have to use a stochastic methodology to forecast mortality rates and life expectancy. For example, they could use the

\footnotetext{
${ }^{16}$ It is welfare improving that individuals buy annuities at retirement because consumption will be maximised and the risk of outliving one's resources will be removed (Yaari, 1965).

${ }^{17}$ As oppose to a situation where the individual bears the longevity risk.
} 
Lee-Carter and the Splines approaches (Antolin, 2006; and CMI, 2005, 2006). A stochastic approach permits to gauge the uncertainty surrounding future mortality and life expectancy outcomes and its associated risks (i.e. longevity risk) because it attaches probabilities to different outcomes. With the aid of for example the Lee-Carter stochastic approach and by means of frequency distributions and cumulated probabilities generated from 10,000 Monte-Carlo simulations of the Lee-Carter model of mortality (Antolin, 2006) ${ }^{18}$ the LRI can be calculated as follows.

41. The Lee-Carter approach, or any other stochastic approach, would provide a central forecast for the life expectancy at a particular age, for example at age 65, and in a particular year, for example 2050. This central forecast is for example a life expectancy of 21 years when reaching age 65 (Figure 1). Moreover, because the approach is stochastic, it permits to generate 10,000 Monte-Carlo simulations using random number generators for the random terms in the Lee-Carter equations. The result of such exercise is a frequency distribution and a cumulative probability for life expectancy at age 65 in 2050 (Figure 1). The cumulative probability function in Figure 1 provides the probability or likelihood that life expectancy will be lower or equal than a determined forecast value. For example, the central forecast of life expectancy of 21 years when reaching age 65 will occur in 73.1 cases out of 100. Moreover, Figure 1 also shows that the central forecast lays above the median life expectancy, that is, the likelihood that life expectancy will turn out higher than the central forecasts is lower than 50 percent. In particular, only in 26.9 of a 100 cases life expectancy will be higher than the central forecasts. In addition, the probability of any deviation regarding life expectancy is also easy to determine. For example, there is 17.9 percent likelihood that life expectancy at age 65 in 2050 will be one year higher than the central forecast. ${ }^{19}$

[Figure 1. Histogram and cumulative probability of life expectancy at age 65 in 2050]

42. Therefore, using the cumulative probability distribution, governmental agencies could calculate a longevity risk index indicating the probability that life expectancy for example at age 65 deviates by 1 year from the central forecast in 2050 , LRI $(\mathrm{i}, \mathrm{t}, \mathrm{m})=(65,2050,1)$ for different subgroups of the population. Doing this for all ages i, for all years from 10 to 75 years after the latest available information, and for deviations of 1 to 10 years, they could construct a matrix for different population subgroups. This information can then be used by annuity providers and pension funds to assess the longevity risk inherent in their membership structure.

\section{Conclusions}

43. This paper has examined the role that governments can play in promoting or encouraging capital market solutions of transferring the longevity risk of pension funds and annuity providers. Financial markets (including insurance) work efficiently for sharing individual risks and short-term risks between cohorts (with largely overlapping lifetimes) but not for the long-term life risks of older cohorts that are largely known when the younger cohorts arrive. Ex ante efficient intergenerational risk sharing via private markets is therefore not possible as future generations cannot be included. These considerations set the stage for the central public policy issue what (capital market) role (if any) the government can play in overcoming these hindrances.

44. The paper argues that this public policy role is hampered by the fact that governments themselves are already exposed to significant longevity risk. This means that issuing longevity-indexed government

\footnotetext{
${ }^{18}$ Monte-Carlo is a technique that involves using random numbers. In particular, it produces simulations of the LeeCarter model by using random number generators for the random terms in the Lee-Carter equations (1) and (2). The Stata programmes, available upon request, assume that the mean and the variance of $\varepsilon(x, t)$ and $e(t)$ are those obtained from the errors of fitting the Lee-Carter model to the historical data.

${ }^{19} \operatorname{Pr}(\mathrm{LEx} \leq \mathrm{LExc}+1)-\operatorname{Pr}(\mathrm{LEx} \leq \mathrm{LExc})=0.91-73.1=17.9$, where LExc is the central forecast.
} 
bonds would further increase their current exposure. On this basis, the paper concludes that the prospects for a successful, large scale market in longevity-indexed bonds seem not favourable at this stage. Nevertheless, governments should weigh the negative impact of this exposure to longevity risk against the benefits of an increase of private provision at retirement resulting from an improved annuity market as a result of issuing longevity indexed bonds.

45. However, the paper suggests that governments can take other steps such as producing a longevity index. Governments, through their national statistical institutes, could encourage or support the development of a private market in longevity hedging products by producing a reliable and widely accepted longevity index to be used as a benchmark for pricing hedging products. Alternatively, they could make the data and information necessary to produce such index widely available. 


\section{REFERENCES}

Antolin, P. (2006), "Longevity Risk and Private Pensions". Forthcoming OECD Discussion Paper on Insurance and Private Pension Issues.

Blommestein, Hans J. (2006), "What are the factors for a successful market in longevity-indexed government bonds (LIBs)? A public debt management perspective" Pensions Management - An International Journal, volume 11, Issue 2, Palgrave McMillan.

Blake D, and W. Burrows (2001), "Survivor Bonds: Helping to Hedge Mortality Risk" Journal of Risk and Insurance 68, 339-348.

Bohn, Henning (2005), "Who Bears What Risk? An Intergenerational Perspective, Pension Research Council Working Paper PRC WP 2005-7.

Brown, J.R. and Peter R. Orszag (2006), “The Political Economy of Government Issued Longevity Bonds", Paper presented at the Second International Longevity Risk and Capital Market Solutions Conference, April.

Byrne, Alistair and Debbie Harrison (2005), "Is longevity risk a one-way market?" Report of the First International Conference on Longevity Risk and Capital Market Solutions, held on 18 February 2005, London.

Cairns, A., D. Blake, P. Dawson and K. Dowd (2005), "Pricing the Risk on Longevity Bonds", Life and Pensions, October: 41-44.

Continuous Mortality Investigation, CMI, (2005a), "Projecting future mortality: Towards a proposal for a stochastic methodology", Mortality Committee, Working Paper 15.

Continuous Mortality Investigation, CMI, (2006), "Stochastic projection methodologies: Further progress and P-spline model features, example results and implications", Mortality Committee, Working Paper 20.

European Commission (2006), "The Impact of Ageing on Public Expenditure: Projections for the EU25 Member States on pension, health care, long-term care, education and unemployment transfers (2004-2050)" European Economy Special Report 1/2006.

Fernandes, F. (2005), "Longevity Bond: A pension fund perspective", Presentation at the First International Conference on Longevity Risk and Capital Market Solutions, held on 18 February 2005, London.

Friedberg, L. and A. Webb (2005), "Life is cheap: using mortality bonds to hedge aggregate mortality risk" Center for Retirement Research Working Paper 2005-13.

Heller, Peter (2003), "Who Will Pay? Coping with Aging Societies, Climate Change and Other Long-Term Fiscal Challenges" IMF, Washington D.C. 
OECD Working Paper on Insurance and Private Pensions

Richards, Stephen and Gavin Jones (2004), "Financial aspects of longevity risk", Paper presented to the Staple Inn Actuarial Society, London, 26 October 2005.

Roberts, Philip (2005), “A practical framework for facilitating longevity risk transfer”, Presentation at the First International Conference on Longevity Risk and Capital Market Solutions, 18 February 2005, London.

Yaari, M. (1965), "Uncertain Lifetime, Life Insurance, and the Theory of Consumer", Review of Economic Studies, Vol. 32, No. 2. 


\section{TABLES AND FIGURES}

Histogram: Life expectancy at age $\mathbf{6 5}$ in 2050

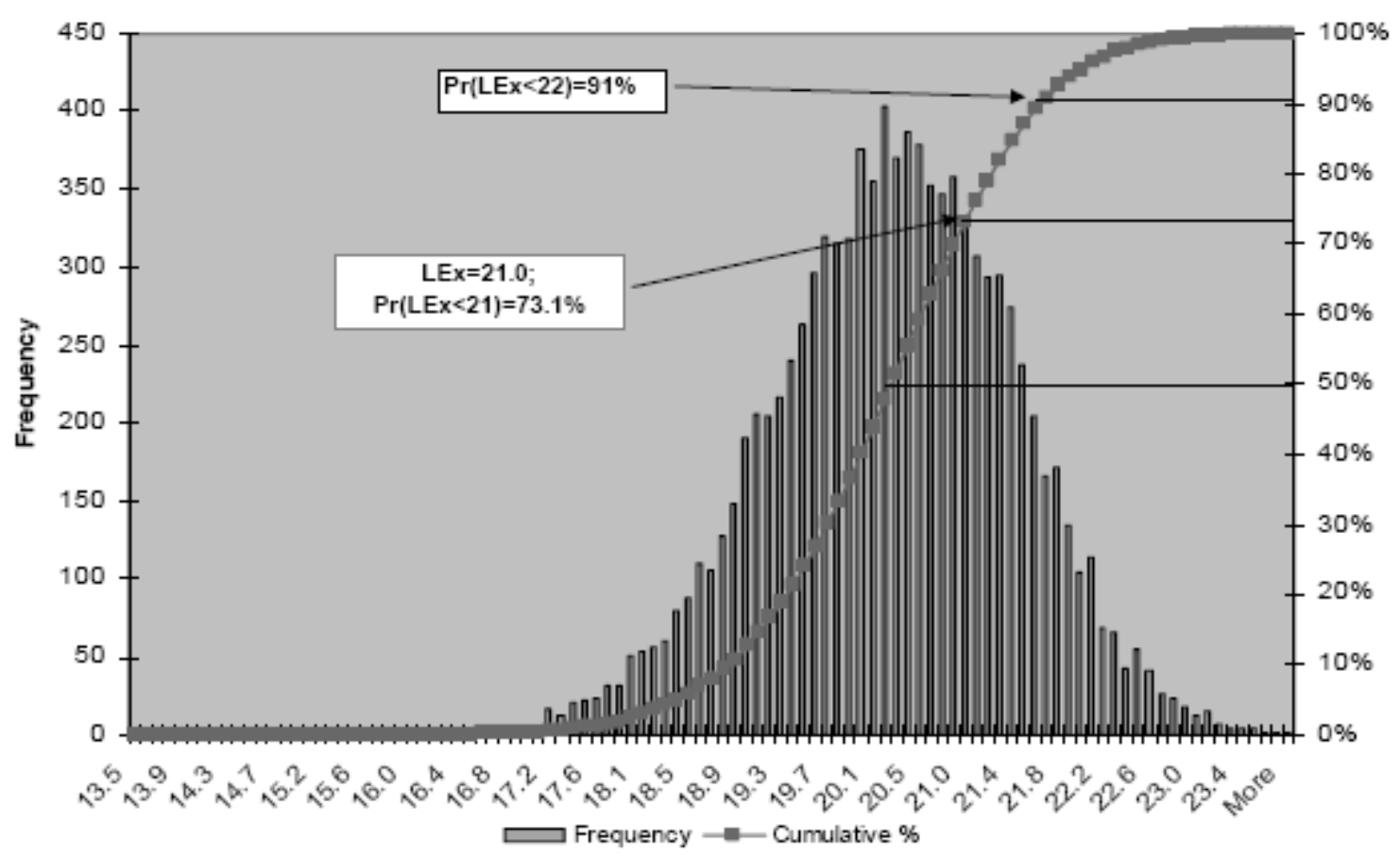


OECD Discussion Paper on Insurance and Private Pension Issues

Table 1 Projected changes in the size and age structure of the population, 2004-2050.

\begin{tabular}{|c|c|c|c|c|c|c|c|c|c|c|c|c|c|c|c|c|c|c|}
\hline & \multicolumn{8}{|c|}{ Population (millions) } & \multicolumn{10}{|c|}{ Dependency ratio (\%) } \\
\hline & \multicolumn{2}{|c|}{ Total } & \multicolumn{2}{|c|}{$\begin{array}{c}\text { Working age } \\
(15-64)\end{array}$} & \multicolumn{2}{|c|}{$\begin{array}{c}\text { Old age } \\
(65+)\end{array}$} & \multicolumn{2}{|c|}{$\begin{array}{c}\text { Very old } \\
(80+)\end{array}$} & \multicolumn{3}{|c|}{$\begin{array}{l}\text { Old age population } \\
\text { over working age }\end{array}$} & \multicolumn{3}{|c|}{$\begin{array}{c}\text { People aged } 65-79 \\
\text { over working age }\end{array}$} & \multicolumn{3}{|c|}{$\begin{array}{l}\text { Very old population } \\
\text { over working age }\end{array}$} & \multirow{2}{*}{$\begin{array}{c}\% \text { change } \\
\text { due to } \\
\text { people } \\
\text { aged } 80+\end{array}$} \\
\hline & 2004 & 2050 & 2004 & 2050 & 2004 & 2050 & 2004 & 2050 & 2004 & 2050 & $\begin{array}{l}\text { Diffe_ } \\
\text { rence }\end{array}$ & 2004 & 2050 & $\begin{array}{l}\text { Diffe_ } \\
\text { rence }\end{array}$ & 2004 & 2050 & $\begin{array}{l}\text { Diffe_ } \\
\text { rence }\end{array}$ & \\
\hline BE & 10.4 & 10.8 & 6.8 & 6.3 & 1.8 & 3.0 & 0.4 & 1.2 & 26.5 & 47.6 & 21.1 & 20.6 & 28.6 & 8.0 & 5.9 & 19.0 & 13.2 & 62.3 \\
\hline DK & 5.4 & 5.5 & 3.6 & 3.3 & 0.8 & 1.4 & 0.2 & 0.5 & 22.2 & 42.4 & 20.2 & 16.7 & 27.3 & 10.6 & 5.6 & 15.2 & 9.6 & 47.5 \\
\hline DE & 82.5 & 77.7 & 55.5 & 45.0 & 14.9 & 23.3 & 3.4 & 9.9 & 26.8 & 51.8 & 24.9 & 20.7 & 29.8 & 9.1 & 6.1 & 22.0 & 15.9 & 63.7 \\
\hline GR & 11.0 & 10.7 & 7.5 & 5.9 & 2.0 & 3.6 & 0.4 & 1.2 & 26.7 & 61.0 & 34.4 & 21.3 & 40.7 & 19.3 & 5.3 & 20.3 & 15.0 & 43.7 \\
\hline ES & 42.3 & 43.0 & 29.1 & 22.9 & 7.1 & 15.0 & 1.8 & 5.3 & 24.4 & 65.5 & 41.1 & 18.2 & 42.4 & 24.1 & 6.2 & 23.1 & 17.0 & 41.3 \\
\hline FR & 59.9 & 65.1 & 39.0 & 37.4 & 9.8 & 17.4 & 2.6 & 6.9 & 25.1 & 46.5 & 21.4 & 18.5 & 28.1 & 9.6 & 6.7 & 18.4 & 11.8 & 55.1 \\
\hline IE & 4.0 & 5.5 & 2.7 & 3.2 & 0.4 & 1.4 & 0.1 & 0.4 & 14.8 & 43.8 & 28.9 & 11.1 & 31.3 & 20.1 & 3.7 & 12.5 & 8.8 & 30.4 \\
\hline IT & 57.9 & 53.8 & 38.5 & 29.3 & 11.1 & 18.2 & 2.8 & 7.2 & 28.8 & 62.1 & 33.3 & 21.6 & 37.5 & 16.0 & 7.3 & 24.6 & 17.3 & 52.0 \\
\hline LU & 0.5 & 0.6 & 0.3 & 0.4 & 0.1 & 0.1 & 0.0 & 0.1 & 33.3 & 25.0 & -8.3 & 33.3 & 0.0 & -33.3 & 0.0 & 25.0 & 25.0 & $\ldots$ \\
\hline $\mathrm{NL}$ & 16.3 & 17.6 & 11.0 & 10.6 & 2.3 & 4.3 & 0.6 & 1.6 & 20.9 & 40.6 & 19.7 & 15.5 & 25.5 & 10.0 & 5.5 & 15.1 & 9.6 & 49.0 \\
\hline AT & 8.1 & 8.2 & 5.5 & 4.7 & 1.3 & 2.5 & 0.3 & 1.0 & 23.6 & 53.2 & 29.6 & 18.2 & 31.9 & 13.7 & 5.5 & 21.3 & 15.8 & 53.5 \\
\hline PT & 10.5 & 10.1 & 7.1 & 5.5 & 1.8 & 3.2 & 0.4 & 1.1 & 25.4 & 58.2 & 32.8 & 19.7 & 38.2 & 18.5 & 5.6 & 20.0 & 14.4 & 43.8 \\
\hline $\mathrm{FI}$ & 5.2 & 5.2 & 3.5 & 3.0 & 0.8 & 1.4 & 0.2 & 0.5 & 22.9 & 46.7 & 23.8 & 17.1 & 30.0 & 12.9 & 5.7 & 16.7 & 11.0 & 46.0 \\
\hline SE & 9.0 & 10.2 & 5.8 & 6.0 & 1.5 & 2.5 & 0.5 & 0.9 & 25.9 & 41.7 & 15.8 & 17.2 & 26.7 & 9.4 & 8.6 & 15.0 & 6.4 & 40.4 \\
\hline UK & 59.7 & 64.2 & 39.2 & 37.8 & 9.5 & 17.0 & 2.6 & 6.5 & 24.2 & 45.0 & 20.7 & 17.6 & 27.8 & 10.2 & 6.6 & 17.2 & 10.6 & 50.9 \\
\hline CY & 0.7 & 1.0 & 0.5 & 0.6 & 0.1 & 0.3 & 0.0 & 0.1 & 20.0 & 50.0 & 30.0 & 20.0 & 33.3 & 13.3 & 0.0 & 16.7 & 16.7 & 55.6 \\
\hline $\mathrm{CZ}$ & 10.2 & 8.9 & 7.2 & 5.0 & 1.4 & 2.8 & 0.3 & 0.8 & 19.4 & 56.0 & 36.6 & 15.3 & 40.0 & 24.7 & 4.2 & 16.0 & 11.8 & 32.4 \\
\hline EE & 1.4 & 1.1 & 0.9 & 0.7 & 0.2 & 0.3 & 0.0 & 0.1 & 22.2 & 42.9 & 20.6 & 22.2 & 28.6 & 6.3 & 0.0 & 14.3 & 14.3 & 69.2 \\
\hline $\mathrm{HU}$ & 10.1 & 8.9 & 6.9 & 5.2 & 1.6 & 2.5 & 0.3 & 0.8 & 23.2 & 48.1 & 24.9 & 18.8 & 32.7 & 13.9 & 4.3 & 15.4 & 11.0 & 44.3 \\
\hline LT & 3.4 & 2.9 & 2.3 & 1.7 & 0.5 & 0.8 & 0.1 & 0.3 & 21.7 & 47.1 & 25.3 & 17.4 & 29.4 & 12.0 & 4.3 & 17.6 & 13.3 & 52.5 \\
\hline LV & 2.3 & 1.9 & 1.6 & 1.1 & 0.4 & 0.5 & 0.1 & 0.2 & 25.0 & 45.5 & 20.5 & 18.8 & 27.3 & 8.5 & 6.3 & 18.2 & 11.9 & 58.3 \\
\hline MT & 0.4 & 0.5 & 0.3 & 0.3 & 0.1 & 0.1 & 0.0 & 0.0 & 33.3 & 33.3 & 0.0 & 33.3 & 33.3 & 0.0 & 0.0 & 0.0 & 0.0 & 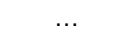 \\
\hline PL & 38.2 & 33.7 & 26.7 & 19.4 & 5.0 & 9.9 & 0.9 & 3.0 & 18.7 & 51.0 & 32.3 & 15.4 & 35.6 & 20.2 & 3.4 & 15.5 & 12.1 & 37.4 \\
\hline SK & 5.4 & 4.7 & 3.8 & 2.7 & 0.6 & 1.4 & 0.1 & 0.4 & 15.8 & 51.9 & 36.1 & 13.2 & 37.0 & 23.9 & 2.6 & 14.8 & 12.2 & 33.8 \\
\hline SI & 2.0 & 1.9 & 1.4 & 1.1 & 0.3 & 0.6 & 0.1 & 0.2 & 21.4 & 54.5 & 33.1 & 14.3 & 36.4 & 22.1 & 7.1 & 18.2 & 11.0 & 33.3 \\
\hline EU25 & 456.8 & 453.8 & 306.8 & 259.1 & 75.3 & 133.3 & 18.2 & 49.9 & 24.5 & 51.4 & 26.9 & 18.6 & 32.2 & 13.6 & 5.9 & 19.3 & 13.3 & 49.5 \\
\hline $\begin{array}{l}\text { EU15 } \\
\text { Euro }\end{array}$ & 382.7 & 388.3 & 255.1 & 221.3 & 65.2 & 114.2 & 16.3 & 44.2 & 25.6 & 51.6 & 26.0 & 19.2 & 31.6 & 12.5 & 6.4 & 20.0 & 13.6 & 52.2 \\
\hline area & 308.6 & 308.4 & 206.5 & 174.2 & 53.3 & 93.4 & 13.0 & 36.3 & 25.8 & 53.6 & 27.8 & 19.5 & 32.8 & 13.3 & 6.3 & 20.8 & 14.5 & 52.3 \\
\hline
\end{tabular}

Source: EC (2006) and OECD calculations. 
OECD Discussion Paper on Insurance and Private Pension Issues

Table 2. Change in public pension expenditure from 2004 to 2050, contributions to this change and sensitivity analysis.

(percentage points of GDP)

\begin{tabular}{|c|c|c|c|c|c|c|c|c|}
\hline & & & & & e to growth $\mathrm{i}$ & & & Increase in \\
\hline & $\begin{array}{l}\text { Expen } \\
\text { public }\end{array}$ & $\begin{array}{l}\text { diture on } \\
\text { pensions }\end{array}$ & $\begin{array}{c}\text { Dependency } \\
\text { ratio }\end{array}$ & $\begin{array}{c}\text { Employment } \\
\text { rate }\end{array}$ & $\begin{array}{l}\text { Take up } \\
\text { ratio }\end{array}$ & Benefit ratio & & $\begin{array}{c}\text { pension } \\
\text { expenditure }\end{array}$ \\
\hline & 2005 & $\begin{array}{c}\text { p.p. } \\
\text { change } \\
2005-2050\end{array}$ & $\begin{array}{c}\text { Pop 65+/ } \\
\text { Pop(15-64) }\end{array}$ & $\begin{array}{l}\text { Employed/ } \\
\text { pop(15-64) }\end{array}$ & $\begin{array}{l}\text { Pensioners } \\
\text { /Pop 65+ }\end{array}$ & $\begin{array}{c}\text { Average } \\
\text { pension/GDP } \\
\text { per worker }\end{array}$ & $\begin{array}{c}\text { Interaction } \\
\text { effect } \\
\text { (residual) }\end{array}$ & $\begin{array}{l}\text { as a result of } \\
\text { higher life } \\
\text { expectancy }\end{array}$ \\
\hline BE & 10.4 & 5.1 & 7.7 & -1.5 & -0.4 & -0.6 & -0.1 & 0.5 \\
\hline DK & 9.6 & 3.2 & 7.2 & -0.4 & -2.8 & -0.5 & -0.3 & \\
\hline DE & 11.1 & 1.9 & 7.5 & -1.1 & -0.6 & -3.5 & -0.4 & 0.2 \\
\hline ES & 8.7 & 7.0 & 12.4 & -1.8 & -2.3 & -0.8 & -0.4 & 0.1 \\
\hline FR & 12.8 & 2.0 & 8.7 & -0.9 & -1.8 & -3.5 & -0.5 & 0.6 \\
\hline IE & 4.6 & 6.5 & 7.9 & -0.5 & -1.4 & 0.8 & -0.2 & \\
\hline IT & 14.3 & 0.4 & 11.5 & -2.0 & -3.2 & -5.3 & -0.7 & 0.3 \\
\hline LU & 10.0 & 7.4 & 7.2 & -4.4 & 2.5 & 2.1 & 0.0 & -0.1 \\
\hline NL & 7.4 & 3.8 & 6.3 & -0.2 & -1.6 & -0.4 & -0.3 & 0.8 \\
\hline AT & 13.2 & -1.0 & 11.3 & -1.3 & -5.8 & -4.3 & -0.8 & 0.4 \\
\hline PT & 11.5 & 9.3 & 13.7 & -0.2 & -0.9 & -3.0 & -0.4 & 0.6 \\
\hline $\mathrm{FI}$ & 10.4 & 3.3 & 8.8 & -0.9 & -3.1 & -0.9 & -0.6 & 0.2 \\
\hline SE & 10.4 & 0.9 & 4.8 & -0.6 & -0.2 & -2.8 & -0.2 & 0.4 \\
\hline UK & 6.7 & 1.9 & 4.7 & -0.1 & & & -2.6 & \\
\hline CY & 7.0 & 12.8 & 10.2 & -1.2 & 1.2 & 2.5 & 0.1 & -0.1 \\
\hline CZ & 8.5 & 5.6 & 10.5 & -0.3 & -3.5 & -0.6 & -0.6 & 0.4 \\
\hline EE & 7.1 & -3.0 & 3.1 & -0.6 & -1.5 & -3.8 & -0.2 & 0.1 \\
\hline $\mathrm{HU}$ & 10.7 & 6.4 & 10.5 & -1.1 & -4.5 & 2.0 & -0.4 & -0.3 \\
\hline LT & 6.7 & 1.9 & 5.4 & -1.0 & -2.1 & -0.2 & -0.2 & 0.4 \\
\hline LV & 6.4 & -0.9 & 3.4 & -0.7 & -1.3 & -2.4 & 0.0 & 0.2 \\
\hline MT & 7.5 & -0.5 & 7.3 & -1.2 & -1.0 & -5.0 & -0.6 & 0.5 \\
\hline PL & 13.7 & -5.7 & 10.4 & -3.2 & -4.5 & -7.5 & -0.8 & 0.2 \\
\hline SK & 7.4 & 1.5 & 9.0 & -1.3 & -2.5 & -3.1 & -0.6 & 0.4 \\
\hline SI & 11.0 & 7.3 & 13.3 & -1.0 & -3.6 & -0.9 & -0.6 & -0.4 \\
\hline EU15 & 10.5 & 2.3 & 8.2 & -1.0 & -1.7 & -2.8 & -0.4 & 0.3 \\
\hline EU25 & 10.6 & 2.2 & 8.6 & -1.1 & -2.1 & -2.7 & -0.4 & 0.3 \\
\hline
\end{tabular}

Souce: EC(2006), Tables 3.3.; 3.10; and 3.29

Notes: Life expectancy one year higher in 2050 relative to baseline projection. 